\title{
Regulatory role of microRNA-185 in the recovery process after ankle fracture
}

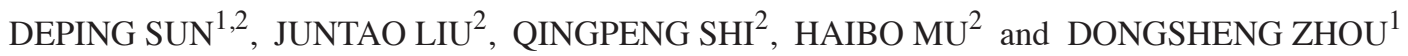 \\ ${ }^{1}$ Department of Orthopedics, Shandong Provincial Hospital Affiliated to Shandong University, Jinan, Shandong 250021; \\ ${ }^{2}$ Department of Orthopedic Trauma, Yantai Affiliated Hospital of Binzhou Medical University, \\ Yantai, Shandong 264000, P.R. China
}

Received July 30, 2017; Accepted July 10, 2018

DOI: $10.3892 /$ etm.2018.6534

\begin{abstract}
The present study aimed to investigate the expression of microRNA (miR)-185 in the bone and blood tissues following ankle fracture, and its regulatory mechanism in the ankle fracture recovery process. In total, 28 patients with ankle fractures were included, including 15 cases receiving surgical treatment within 1-7 days after fracture, and 13 cases receiving surgery within 8-14 days after fracture. Reverse transcription-quantitative polymerase chain reaction was performed to detect the mRNA expression levels. Western blot analysis and ELISA were used to determine the protein expression levels. Bioinformatics analysis and dual-luciferase reporter assay were applied to predict and confirm the upstream regulator of tumor growth factor (TGF)- $\beta 1$. An MTT assay was performed to assess the cell proliferation. Compared with the 1-7-day surgery group, the mRNA and protein expression levels of TGF- $\beta 1$ were significantly elevated, while the expression levels of miR-185 were significantly declined in the bone and blood tissues in the 8-14-day surgery group. Bioinformatics analysis and dual-luciferase reporter assay predicted and confirmed that TGF- $\beta 1$ was the direct target gene of miR-185. Moreover, upregulated expression of miR-185 significantly decreased the protein expression levels of TGF- $\beta 1$ and reduced the proliferating activity of hFOB1.19 cells. Within two weeks after ankle fracture, the expression levels of TGF- $\beta 1$ are significantly upregulated in the bone and blood tissues, which may have been associated with the downregulated expression of miR-185. miR-185 may modulate TGF- $\beta 1$ to regulate the recovery of ankle fracture. These findings may contribute to the understanding of the biological functions and effects of miRNA-185 and TGF- $\beta 1$ in ankle fractures.
\end{abstract}

Correspondence to: Dr Dongsheng Zhou, Department of Orthopedics, Shandong Provincial Hospital Affiliated to Shandong University, 324 Jingwu Road, Jinan, Shandong 250021, P.R. China E-mail: sdpsdp111@126.com

Key words: ankle fracture, recovery process, microRNA-185, TGF- $\beta 1$, dual-luciferase reporter assay

\section{Introduction}

Ankle fracture is a common kind of orthopedic trauma, with increasing incidence along with the social aging process (1). Most ankle fracture cases are caused by indirect violence (such as physical labor, strenuous exercise, and car accident injuries), more usually seen in young adults, which accounts for about $3.9 \%$ of all body fracture cases (2,3). Accompanied along with the bone fracture is a series of changes in microRNA (miRNA or miR) and mRNA in the body, which has become the focus of disease diagnosis and treatment (4-6).

Tumor growth factor (TGF)- $\beta 1$ belongs to the TGF superfamily, which is produced by various kinds of cells. In the bone tissue, TGF- $\beta 1$ is mainly produced by osteocytes, osteoblasts, osteoclasts, and chondrocytes. Osteoblast-produced TGF- $\beta 1$ will bind to the bone matrix soon after generation (7). It has been proven that TGF- $\beta 1$ stimulates collagen synthesis, and it is a potent chemokine, which increases the extracellular matrix and plays an important role in regulating bone and cartilage formation (8). Moreover, it has been shown that several miRs regulate the activity of TGF- $\beta 1$ signaling pathway $(9,10)$. However, for the recovery following ankle fracture, the role of TGF- $\beta 1$ and its up-stream miRNA regulators has not yet been full established.

In the present study, the miR-185-related TGF- $\beta 1$ effects in the recovery process after ankle fracture were investigated. Quantitative real-time PCR, Western blot analysis, gene bioinformatics, and ELISA were performed to study the mRNA and protein expression levels of TGF- $\beta 1$ in the bone tissue and blood samples from the ankle fracture patients receiving surgical treatment at different time points. Its relation with miR-185 was also predicted and confirmed, and the biological functions of miR-185 in osteoblasts were explored.

\section{Materials and methods}

Study subjects. A total of 28 patients of ankle fracture were including in the present study, who received surgical treatment in our hospital from August 2013 to March 2017. In these patients, 15 cases receive the surgical treatment during 1-7 days after ankle fracture, including 8 males and 7 females, aging from 25 to 58 years. The other 13 cases received surgical treatment during 8-14 days after ankle fracture, including 
8 males and 3 females, aging from 23 to 60 years. Written informed consent were obtained from every patient prior to the beginning of the study and the study was approved by the Ethics Review Board of the Shandong Provincial Hospital Affiliated to Shandong University.

Sample collection preparation. Peripheral blood samples were collected from all these patients on the morning of surgery day under fast condition, which were stored at $-20^{\circ} \mathrm{C}$ after EDTA anticoagulation. Bone tissue from the fracture site was obtained during surgery and stored in liquid nitrogen. The bone tissue was weighted and grinded into powder in liquid nitrogen in a mortar. The tissue was then in $1.5 \mathrm{ml}$ EP tubes until further mRNA and protein extraction.

Quantitative real-time PCR. Total RNA was extracted with Trizol. The cDNA templates were obtained with the reverse transcription, and store at $-20^{\circ} \mathrm{C}$. Quantitative real-time PCR was performed with the SuperReal PreMix (SYBR-Green) (FP204; Tiangen Biotech Co., Ltd., Beijing, China) on an iQ5 PCR instrument (Bio-Rad Laboratories, Inc., Hercules, CA, USA). For the detection of TGF- $\beta 1$ mRNA levels, primer sequences for the quantitative real-time PCR were as follows: TGF- $\beta 1$, forward 5'-GGACACCAACTATTGCTT CAG-3' and reverse 5'-TCCAGACTCCAAATGTAG-3'; and $\beta$-actin, forward 5'-TTCCAGCCTTCCTTCCTGG-3' and reverse 5'-TTGCGCTCAGGAGGAGGAAT-3'. The 20- $\mu 1$ PCR reaction system consisted of $10 \mu \mathrm{l}$ qRT-PCR-Mix, $0.5 \mu \mathrm{l}$

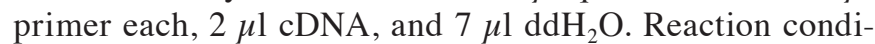
tions were as follows: $95^{\circ} \mathrm{C}$ for $2 \mathrm{~min} ; 94^{\circ} \mathrm{C}$ for $45 \mathrm{sec}, 55^{\circ} \mathrm{C}$ for $55 \mathrm{sec}, 72^{\circ} \mathrm{C}$ for $1 \mathrm{~min}$, for totally 30 cycles; followed by $72^{\circ} \mathrm{C}$ for $10 \mathrm{~min}$. On the other hand, primer sequences for the detection of miR-185 in the bone tissue were as follows: miR-185, up-stream 5'-TGGAGAGAAAGGCAG TTCCTGA-3'; and U6, up-stream 5'-GCTTCGGCAGCA CATATACTAAAAT-3'. Universal down-stream primer were used herein, i.e., 5'-CGCTTCACGAATTTGCGTGTCAT-3'. Reaction conditions included $95^{\circ} \mathrm{C}$ for $3 \mathrm{~min} ; 95^{\circ} \mathrm{C}$ for $12 \mathrm{sec}$, $62^{\circ} \mathrm{C}$ for $35 \mathrm{sec}, 62-95^{\circ} \mathrm{C}$ for $15 \mathrm{sec}$, for totally 40 cycles Target gene expression level was calculated with the $2^{-\Delta \Delta \mathrm{Cq}}$ method (11). $\beta$-actin and U6 were used as internal references, respectively.

Western blot analysis. Bone tissue was lysed with the lysis to obtain total protein. After centrifugation at $4^{\circ} \mathrm{C}$ at $12,000 \mathrm{rpm}$ for $15 \mathrm{~min}$, protein concentration was determined by the BCA method (RTP7102; Real-Times, Beijing, China). Totally $20 \mu \mathrm{g}$ protein was subjected to $10 \%$ SDS-PAGE, and then electronically transferred onto a membrane. After blocking with $5 \%$ non-fat milk at room temperature for $1 \mathrm{~h}$, the membrane was incubated with rabbit anti-human anti-TGF- $\beta 1$ (1:500 dilution; ab92486; Abcam, Cambridge, MA, USA) and rabbit anti-human anti- $\beta$-actin (1:5,000 dilution; ab129348; Abcam) primary antibodies, respectively, at $4^{\circ} \mathrm{C}$ overnight. Then the membrane was incubated with goat anti-rabbit secondary antibody (1:3,000 dilution; ab6721; Abcam) at room temperature for $1 \mathrm{~h}$. Protein bands were developed by the ECL method (ab65623; Abcam), and the Image Lab software was used for signal acquisition and analysis. $\beta$-actin was used as internal reference.
Enzyme-linked immunosorbent assay (ELISA). Blood sample was centrifuged at 1,200 x $\mathrm{g}$ for $10 \mathrm{~min}$ to isolate the serum and erythrocytes. Serum level of TGF- $\beta 1$ was detected with a commercially available ELISA kit (ab100674; Abcam), according to the manufacturer's instructions. Standard curve was obtained with the standard samples provided within the kit. On the other hand, $10 \mu \mathrm{l}$ sample and $40 \mu \mathrm{l}$ dilution solution was added into wells, except for the blank wells. Then, $100 \mu \mathrm{l}$ HRP-labeled detection antibody was added. Then the plate was sealed, and placed in the incubator for $1 \mathrm{~h}$. After washing for 5 times, substrates $\mathrm{A}$ and $\mathrm{B}(50 \mu \mathrm{l}$ each) were added into these wells, which were incubated at $37^{\circ} \mathrm{C}$ for $15 \mathrm{~min}$. Then, $50 \mu 1$ stop solution was added into each well, and the OD value at $450 \mathrm{~nm}$ within $15 \mathrm{~min}$.

Bioinformatics prediction and analysis. To further investigate the role of TGF- $\beta 1$ in the regulation of ankle fracture recovery, the existing literature concerning the up-stream miRNAs of TGF- $\beta 1$ was explored, and possible regulating miRNAs for TGF- $\beta 1$ was predicted by the following target gene prediction software: miRanda (http://www.microma.org/rnicroma/home. do), TargetSean (www.targetscan.org), PiTa (http://genie. weizmann.ac.il/pubs/mir07/mir07_data.html), RNA hybrid (http://bibiserv.techfak.uni-bielefeld.de/rnahybrid/), and PICTA (http://pictar.mdc-berlin.de/).

Dual-luciferase reporter assay. Normal and mutant seed regions of miR-185 in the TGF- $\beta 1$ 3'-UTR were chemically synthesized (Sangon Biotech Co., Ltd., Shanghai, China), and Spe-1 and HindIII digestion sites were added to the ends, respectively. Two kinds of DNA fragments were cloned into the PMIR-REPORT luciferase reporter plasmid, and mutant 3'-UTR seed region was used as control. Totally $0.8 \mu \mathrm{g}$ plasmid containing wile-type or mutant 3'-UTR DNA sequence was transfected into the $293 \mathrm{~T}$ cells with liposome, followed by the transfection of $100 \mathrm{nM}$ agomiR-185. After $24 \mathrm{~h}$ incubation, the cells were lysed, and the fluorescence was detected with the GloMax 20/20 luminometer. Renilla was used as internal reference.

Human osteoblast transfection. On one day before transfection, human osteoblast hFOB1.19 cells (The Cell Bank of Chinese Academy of Sciences, Shanghai, China) in the logarithmic growth phase were planted onto the 24 -well plate, at a density of $3 \times 10^{5}$ cells/well. These cells were incubated with the F12/DMEM medium, containing 10\% FBS, without antibiotics. Cell transfection was performed when $70 \%$ confluency was reached. The transfection plasmid/siRNA/agomiR and $1 \mu 1$ lipo2000 were added into an EP tube containing $50 \mu 1$ Opti Memi medium, which was placed at room temperature for $5 \mathrm{~min}$. After another $20 \mathrm{~min}$, the mixture was added into wells to incubate the cells for $6 \mathrm{~h}$, which was then replaced by F12/DMEM medium containing $10 \%$ FBS. After $48 \mathrm{~h}$, the cellular RNA and protein were collected, and the target gene expression levels were determined.

MTT assay. Cell proliferation was assessed with the MTT assay. These cells were seeded onto the 96-well plate, at a density of $2 \times 10^{3}$ cells/well. Totally $20 \mu \mathrm{l}$ MTT $(5 \mathrm{~g} / 1)$ was added into each well at 24,48 , and 72 h, respectively. Twenty 

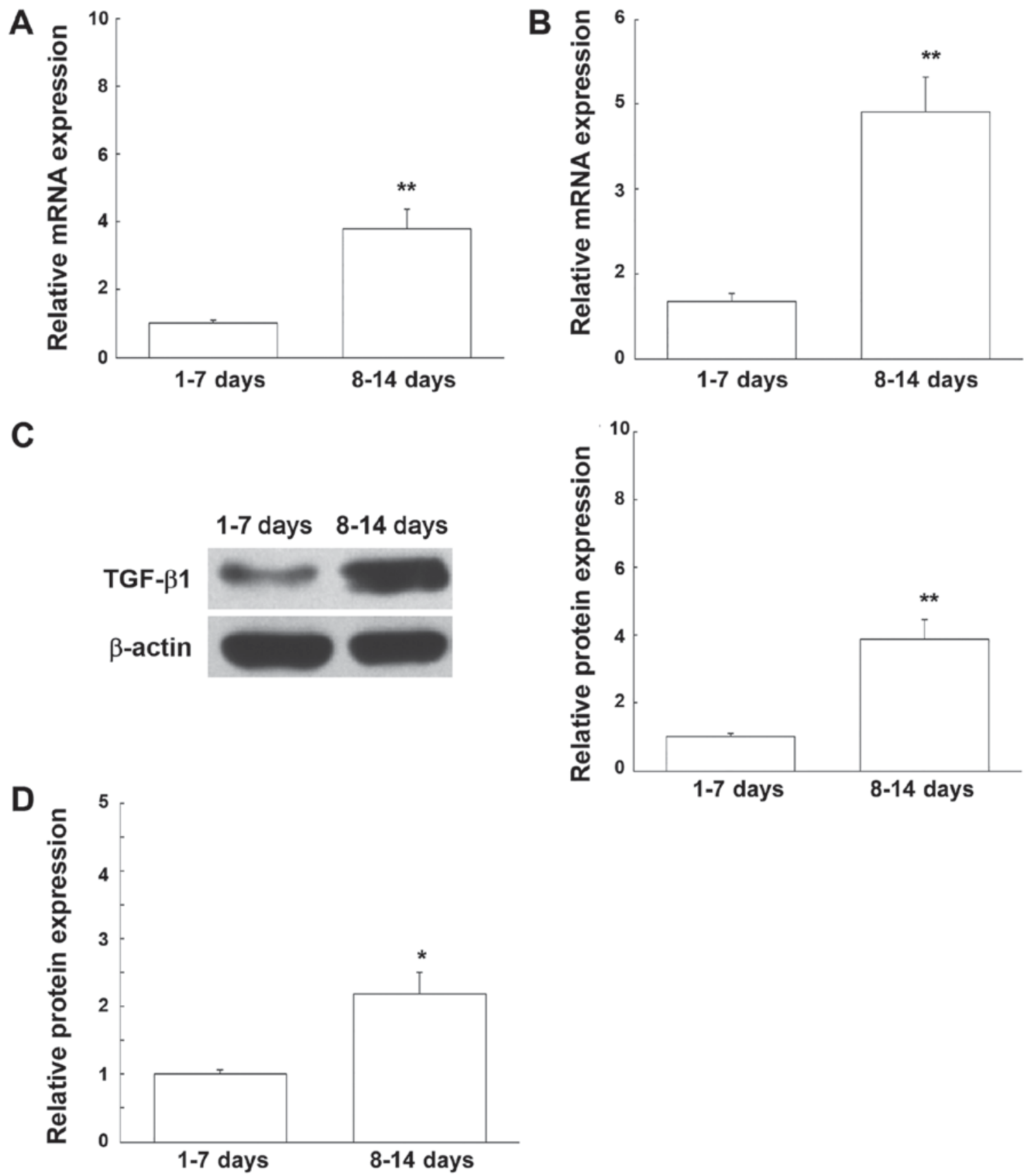

Figure 1. Expression levels of TGF- $\beta 1$ in ankle fracture patients after surgery. (A and B) The mRNA expression levels of TGF- $\beta 1$ in the bone (A) and blood (B) tissues were detected with quantitative real-time PCR. (C and D) The protein expression levels of TGF- $\beta 1$ in the bone (C) and blood (D) tissues were detected with the Western blot analysis and ELISA, respectively. Compared with the $1-7$-day surgery group, ${ }^{*} \mathrm{P}<0.05,{ }^{* * *} \mathrm{P}<0.01$. TGF- $\beta 1$, tumor growth factor (TGF)- $\beta 1$.

four hour later, $150 \mu 1 \mathrm{DMSO}$ was added into each well. After incubated at $37^{\circ} \mathrm{C}$ for $4 \mathrm{~h}$, the absorbance at $490 \mathrm{~nm}$ was determined. Experiment was performed in triplicate. Cell proliferation curve was obtained accordingly.

Statistical analysis. Data were expressed as mean \pm SD. SPSS v.18.0 software (SPSS, Inc., Chicago, IL, USA) was used for statistical analysis. After the Kolmogorov-Smirnov normality test, one-way ANOVA was performed for group comparison, with LSD and SNK tests, and Tamhane's T2 or Dunnett's T3 method, for homogeneous and nonhomogeneous data, respectively. $\mathrm{P}<0.05$ was considered to indicate a statistically significant difference.

\section{Results}

TGF- $\beta 1$ expression levels in ankle fracture patients after surgery. Quantitative real-time PCR was performed to detect the mRNA changes of TGF- $\beta 1$ in the ankle fracture patients receiving surgeries on 1-7 days and 8-14 days, respectively, after fracture. Our results showed that, compared with the 1-7 day surgery group, the mRNA levels of TGF- $\beta 1$ in both bone $(1.00 \pm 0.09$ vs. $3.81 \pm 0.56)$ and blood $(1.00 \pm 0.15$ vs. $4.37 \pm 0.61)$ tissues in the 8-14-day surgery group were significantly elevated $(\mathrm{P}<0.05$; Fig. 1$)$. On the other hand, the protein expression levels of TGF- $\beta 1$ in the boneand blood tissues after ankle fracture were detected with western blot analysis and 
ELISA, respectively. Our results showed that, compared with the 1-7 day surgery group, the protein expression levels of TGF- $\beta 1$ in both the bone $(1.00 \pm 0.11$ vs. $3.89 \pm 0.59)$ and blood $(1.00 \pm 0.06$ vs. $2.18 \pm 0.31)$ tissues were significantly elevated in the 8-14-day surgery group $(\mathrm{P}<0.05 ;$ Fig. 1$)$. Taken together, these results suggest that, within $2 \mathrm{w}$ after humeral fracture, the TGF- $\beta 1$ expression level would be up-regulated gradually, which might play an important role in the regulation of disease recovery.

Prediction and confirmation of up-stream regulator of $T G F-\beta 1$. Bioinformatics analysis provides the basis and clue for miRNA function investigation. Existing literature concerning the up-stream miRNAs of TGF- $\beta 1$ was first retrieved and consulted, which was then subjected to the prediction analysis with the miRanda, TargetSean, PiTa, RNA hybrid, and PICTA software. Our result lead to the miR-185 as the possible up-stream regulator for TGF- $\beta 1$, i.e., 3'-agu ccuUGACGGAAAGAGAGGu-5' hsa-miR-185 197: 5'-acuccc ACUCCCUCUCUCUCCc-3' TGFB1.

Dual-luciferase reporter assay was then performed to confirm the prediction findings. Our results showed that, co-transfection of agomiR-185 and pMIR-REPORT luciferase reporter plasmid significantly declined the fluorescence $(1.00 \pm 0.08$ vs. $0.31 \pm 0.02)(\mathrm{P}<0.05)$, while no significant change was noted for the mutant reporter-transfected group $(1.00 \pm 0.08$ vs. $0.92 \pm 0.10$; Fig. 2$)$. These results suggest that, miR- 185 could bind to the 3 '-UTR of TGF- $\beta 1$, and regulate the gene expression.

MiR-185 expression levels in ankle fracture patients after surgery. The expression levels of miR-185 in the tissues from ankle fracture patients receiving surgery were detected with quantitative real-time PCR. Our results showed that, compared with the 1-7 day surgery group, the miR-185 expression levels in the tissues from ankle fracture patients were significantly down-regulated in the 8-14-day surgery group (for bone, $1.00 \pm 0.12$ vs. $0.33 \pm 0.06$; and for blood, $1.00 \pm 0.06$ vs. $0.29 \pm 0.03)(\mathrm{P}<0.05$; Fig. 3). Together with the prediction and confirmation results, these findings suggest that miR-185 might play a regulatory role in the feedback or recovery process after ankle fracture, possibly via mediating the transcription levels of its target gene TGF- $\beta 1$.

Effects of agomiR-185 transfection on hFOB1.19 human osteoblasts. The effects of agomiR-185 transfection on the hFOB1.19 human osteoblasts were then investigated. Our results showed that, after transfected with agomiR-185, the miR-185 expression level was significantly increased $(1.00 \pm 0.10$ vs. $12.10 \pm 1.61)$, while the protein expression level of TGF- $\beta 1$ was significantly decreased $(1.00 \pm 0.06$ vs. $0.28 \pm 0.05)(\mathrm{P}<0.05)$. Cell proliferation was assessed with the MTT assay. Our results showed that, agomiR-185 significantly reduced the cell proliferating process $\left(\mathrm{OD}_{450}\right.$ ${ }_{\mathrm{nm}}$ : at $48 \mathrm{~h}, 0.71 \pm 0.07,0.70 \pm 0.08$, and $0.60 \pm 0.05$, and at $72 \mathrm{~h}$, $1.36 \pm 0.16,1.26 \pm 0.12$, and $0.96 \pm 0.09$, for the control, NC, and agomiR-185 groups, respectively) $(\mathrm{P}<0.05$; Fig. 4). These results suggest that, agomiR-185 transfection could inhibit the proliferation of hFOB1.19 human osteoblasts via regulating TGF- $\beta 1$ expression.

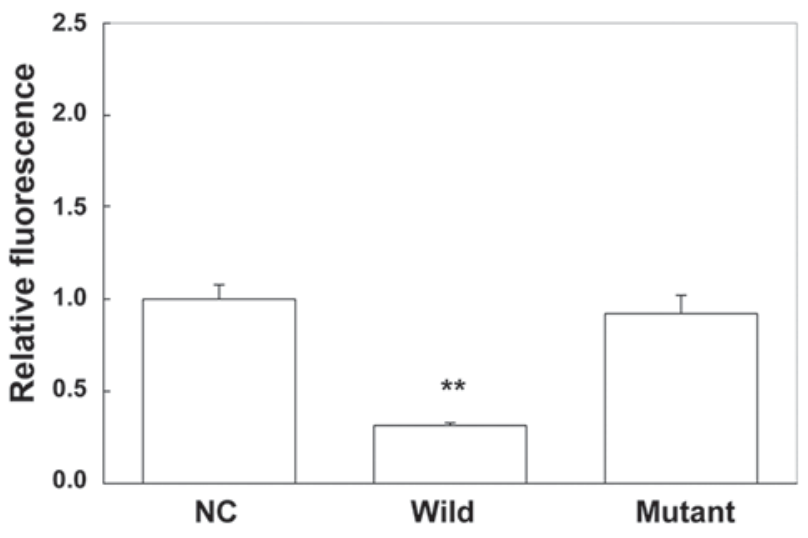

Figure 2. Confirmation of interaction between miR-185 and TGF- $\beta 1$. Dual-luciferase reporter assay was performed to detect the interaction between miR-185 and TGF- $\beta 1$. Compared with the NC group, ${ }^{* *} \mathrm{P}<0.01$. TGF- $\beta 1$, tumor growth factor (TGF)- $\beta 1$

\section{Discussion}

In the present study, the expression levels of TGF- $\beta 1$ in the bone and blood tissues were investigated in the patients of ankle fracture receiving surgical treatment at different time points. Moreover, the expression levels and biological functions of its up-stream regulator, miR-185, were also analyzed. The mechanism of miR-185 regulating TGF- $\beta 1$ in the recovery process of ankle fracture after surgery was preliminarily discussed and studied.

TGF- $\beta 1$ is an important coupling agent in the process of bone remodeling. In the bone tissue, osteoblasts are one of the most sensitive cell lines that are responsive to the mitogen response of TGF- $\beta 1$ (12). TGF- $\beta 1$ obviously contributes to the bone formation process, alone or together with other growth factors. Beige et al (13) have shown that, during the early stage of cartilage formation, TGF- $\beta 1$ is expressed in the cartilage mesenchymal cells, immature chondrocytes, and mature chondrocytes. Joyec et al (14) have found that subperiosteal injection of TGF- $\beta 1$ could induce intramembrane osteogenesis and cartilage formation. Moreover, high-dose TGF- $\beta 1$ induces osteogenesis of periosteal cartilages, and low-dose TGF- $\beta 1$ can directly induce intramembrane osteogenesis. It has been shown that (15), both bone- and platelet-derived TGF- $\beta 1$ can bidirectionally stimulate the DNA synthesis in the fetal mouse skull cells and fetal bovine osteoblasts. Moreover, the DNA synthesis rates would increase, peak, and decrease along with the increasing concentration of TGF- $\beta 1$, and this process is closely related to the degree of cell differentiation. In the present study our results showed that, compared with the 1-7 day surgery group, the mRNA and protein expression levels of TGF- $\beta 1$ in the bone tissue were significantly up-regulated in patients from the 8-14-day surgery group. In line with previous findings, these results suggest that the bone injuries could stimulate the expression of TGF- $\beta 1$, which plays a role in bone repair and regeneration, and also reduces the inflammatory response.

In order to further study the mechanism of the TGF- $\beta 1$ regulation, bioinformatics analysis was performed to predict the up-stream genes of TGF- $\beta 1$. Recent studies have shown that a class of intracellular endogenous non-coding miRNAs 

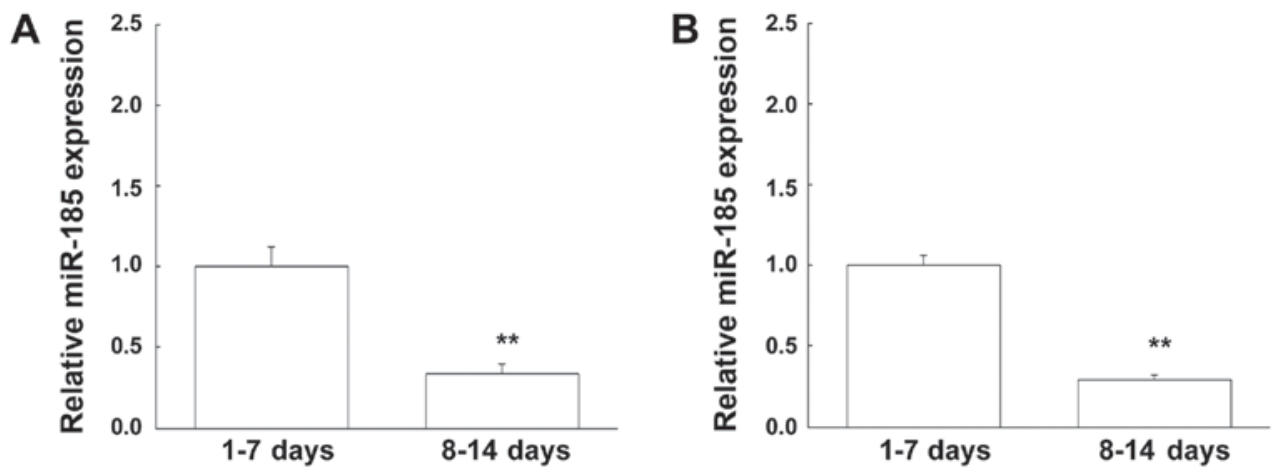

Figure 3. Expression levels of miR-185 in ankle fracture patients after surgery. The expression levels of miR-185 in the bone (A) and blood (B) tissues were detected in the ankle fracture patients after surgery. Compared with the 1-7 day surgery group, ${ }^{* *} \mathrm{P}<0.01$.

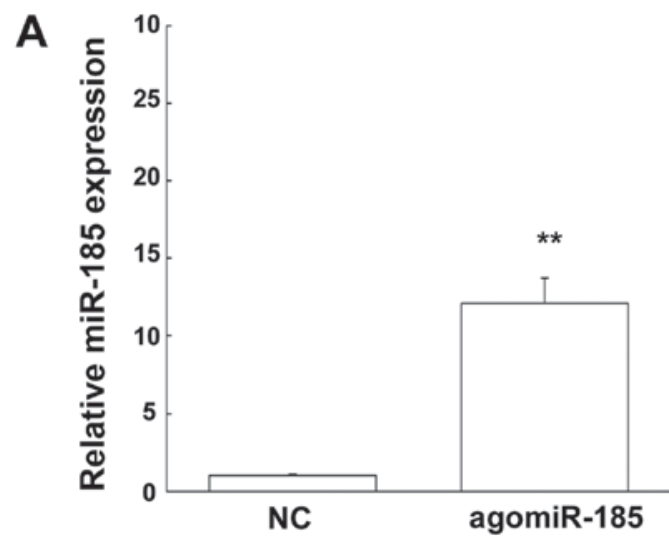

B
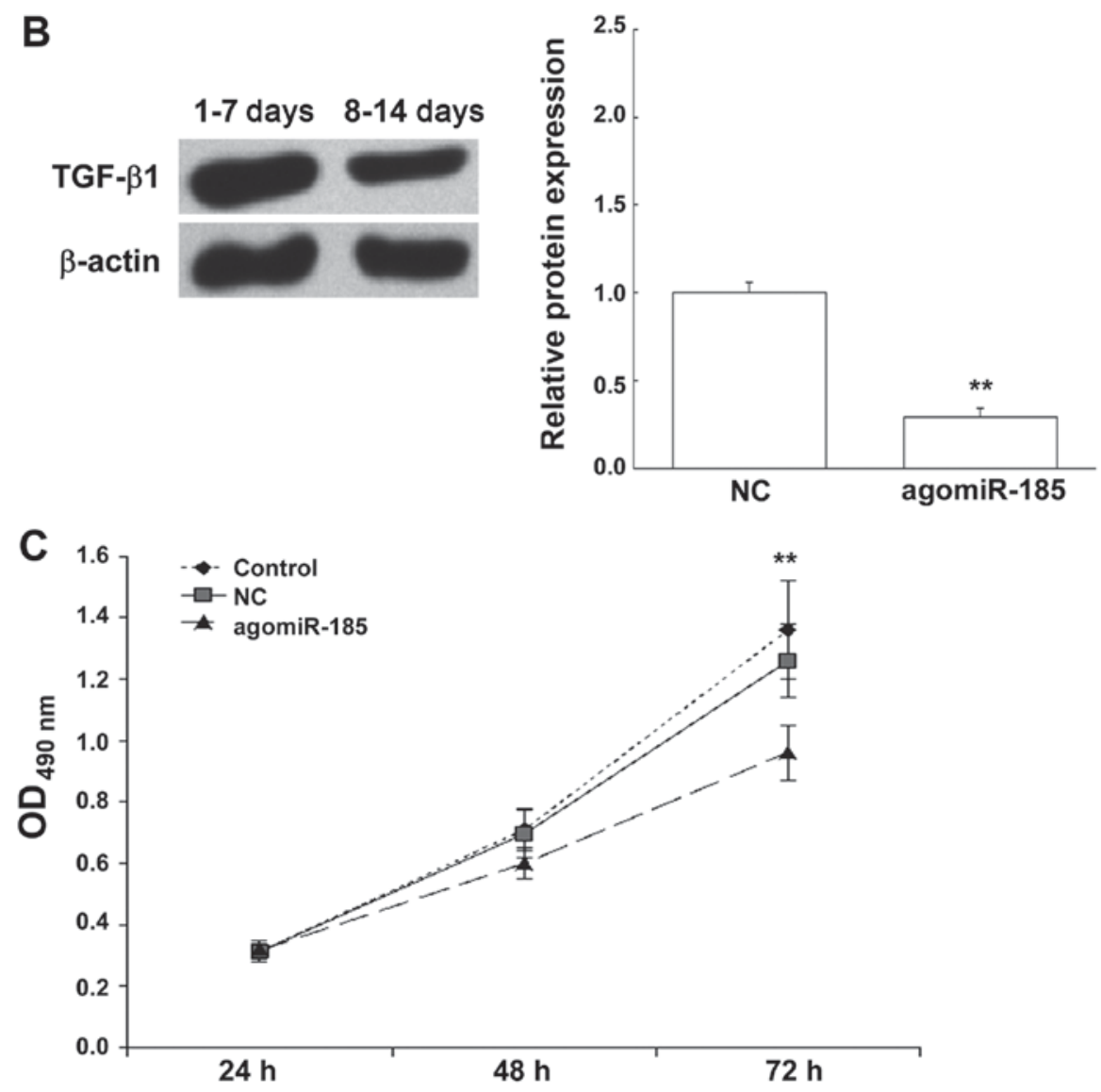

Figure 4. Effects of agomiR-185 transfection on hFOB1.19 human osteoblasts. (A and B) The hFOB1.19 human osteoblasts were transfected with agomiR-185, and the expression levels of miR-185 (A) and TGF- $\beta 1$ (B) were detected. (C) Cell proliferation was assessed with the MTT assay. Compared with the NC group, ${ }^{* *} \mathrm{P}<0.01$. TGF- $\beta 1$, tumor growth factor (TGF)- $\beta 1$. 
may cleave the TGF- $\beta 1$ mRNA and inhibit the mRNA translation (9). MiRNAs exert the regulating functions via cleavage, promoting the mRNA expression to modulate the gene activities $(16,17)$.

Results from prediction showed that miR-185 is closely related to TGF- $\beta 1$, and is likely to be an up-stream regulating miRNA for TGF- $\beta 1$. It is noted that miR-185 is up-regulated to influence the TGF- $\beta 1$ signaling pathway in the chronic benzene poisoning process (18). Previous studies have shown that miRNA-195 might be the target for disease gene prevention, diagnosis, and treatment (18-21). Kim et al (19) have shown that, miR-185 could reverse the cardiac hypertrophy process via multiple signaling pathways. Moreover, Ma et al (20) have found that miR-185 could inhibit the proliferation of transparent cells, renal cells, and tumor cells via the target gene of VEGFA. Furthermore, Bao et al (21) have indicated that miR-185 could target on the SOCS3 gene to inhibit the diabetes-induced $\beta$-cell dysfunction. In addition, Fu et al (22) have demonstrated that miR-185 could inhibit the proliferation and metastasis of human breast cancer cells via the target gene of c-met. Similar activity of miR-185 has also been found in breast cancer, with the target gene of VEGFA (23).

In this study, our results showed the relationship between miR-185 and TGF- $\beta 1$, both in the bone and blood tissues. The expression levels of miR-185 were declined in the both bone and blood tissues, indicating that miR-185 might be the up-stream TGF- $\beta 1$ regulator, influencing the gene transcription and translation, and playing an important role in the recovery process of ankle fracture. In order to confirm the biological effect of miR-185, human osteoblast hFOB1.19 cells were cultured in vitro and transfected with agomiR-185. Our results from MTT assay showed that elevation of miR-185 could obviously inhibit the proliferating activities of hFOB1.19 cells, in which the expression of TGF- $\beta 1$ was notably down-regulated. To further confirm the direct interaction between miR-185 and TGF- $\beta 1$ mRNA, dual-luciferase reporter assay was performed. Our results showed that miR-185 could bind to the 3'-UTR of TGF- $\beta 1$ mRNA, and regulate the expression.

In conclusion, our results showed that miR-185 regulated the expression levels of TGF- $\beta 1$, to inhibit the proliferation of human osteoblasts, and play an important role in the recovery process of ankle fracture. These findings might contribute to the understanding of the biological functions and effects of miRNA-185 and TGF- $\beta 1$ in the ankle fracture.

\section{Acknowledgements}

The authors would like to thank Director Shanhui Li and Director Xiaochun An (Yantai Affiliated Hospital of Binzhou Medical University, Yantai, China) for their assistance in the manuscript preparation.

\section{Funding}

No funding was received.

\section{Availability of data and materials}

All data and materials has been made available in the manuscript.

\section{Authors' contributions}

DS was involved in study design, document reading and analysis, and data collection and analysis. JL, QS and HM were involved in document reading and analysis, and data collection and analysis. DZ was involved in study design, document reading and analysis, manuscript preparation, and final approval for publication.

\section{Ethics approval and consent to participate}

Written informed consent were obtained from every patient prior to the beginning of the study and the study was approved by the Ethics Review Board of the Shandong Provincial Hospital Affiliated to Shandong University.

\section{Patient consent for publication}

Not applicable.

\section{Competing interests}

The authors declare that they have no competing interests.

\section{References}

1. Court-Brown CM, McBirnie J and Wilson G: Adult ankle fractures-an increasing problem? Acta Orthop Scand 69: 43-47, 1998.

2. Mandell JC, Khurana B and Smith SE: Stress fractures of the foot and ankle, part 1: Biomechanics of bone and principles of imaging and treatment. Skeletal Radiol 46: 1021-1029, 2017.

3. Kang P, Tang B, Liu Y, Liu X, Shen Y, Liu Z, Yang H and Zhang L: Profile and procedures for fractures among 1323 fracture patients from the 2010 Yushu earthquake, China. Am J Emerg Med 34: 2132-2139, 2016.

4. Zou L, Zhang G, Liu L, Chen C, Cao X and Cai J: A MicroRNA-124 polymorphism is associated with fracture healing via modulating BMP6 expression. Cell Physiol Biochem 41: 2161-2170, 2017.

5. Gennari L, Bianciardi S and Merlotti D: MicroRNAs in bone diseases. Osteoporos Int 28: 1191-1213, 2017.

6. Huang HM, Li XL, Tu SQ, Chen XF, Lu CC and Jiang LH: Effects of roughly focused extracorporeal shock waves therapy on the expressions of bone morphogenetic protein-2 and osteoprotegerin in osteoporotic fracture in rats. Chin Med J (Engl) 129: 2567-2575, 2016.

7. Hulth A: Current concepts of fracture healing. Clin Orthop Relat Res: 265-284, 1989.

8. Tatsuyama K, Maezawa Y, Baba H, Imamura Y and Fukuda M: Expression of various growth factors for cell proliferation and cytodifferentiation during fracture repair of bone. Eur J Histochem 44: 269-278, 2000.

9. Ma C, Wei F, Xia H, Liu H, Dong X, Zhang Y, Luo Q, Liu Y and Li Y: MicroRNA-10b mediates TGF- $\beta 1$-regulated glioblastoma proliferation, migration and epithelial-mesenchymal transition. Int J Oncol 50: 1739-1748, 2017.

10. Sandbothe M, Buurman R, Reich N, Greiwe L, Vajen B, Gürlevik E, Schäffer V, Eilers M, Kühnel F, Vaquero A, et al: The microRNA-449 family inhibits TGF- $\beta$-mediated liver cancer cell migration by targeting SOX4. J Hepatol 66: 1012-1021, 2017.

11. Livak KJ and Schmittgen TD: Analysis of relative gene expression data using real-time quantitative PCR and the 2(-Delta Delta C(T)) method. Methods 25: 402-408, 2001.

12. Canalis E, McCarthy $\mathrm{T}$ and Centrella M: Growth factors and the regulation of bone remodeling. J Clin Invest 81: 277-281, 1988.

13. Beige J, Kreutz R and Rothermund L: Acute renal failure: Pathophysiology and clinical management. Dtsch Med Wochenschr 132: 2569-2578, 2007 (In German). 
14. Joyce ME, Roberts AB, Sporn MB and Bolander ME: Transforming growth factor-beta and the initiation of chondrogenesis and osteogenesis in the rat femur. J Cell Biol 110: 2195-2207, 1990.

15. Centrella M, McCarthy TL and Canalis E: Transforming growth factor beta is a bifunctional regulator of replication and collagen synthesis in osteoblast-enriched cell cultures from fetal rat bone. J Biol Chem 262: 2869-2874, 1987.

16. Zhao X, Mohan R, Özcan S and Tang X: MicroRNA-30d induces insulin transcription factor MafA and insulin production by targeting mitogen-activated protein 4 kinase 4 (MAP4K4) in pancreatic $\beta$-cells. J Biol Chem 287: 31155-31164, 2012.

17. Chen K and Rajewsky N: The evolution of gene regulation by transcription factors and microRNAs. Nat Rev Genet 8: 93-103, 2007.

18. Bai W, Chen Y, Yang J, Niu P, Tian L and Gao A: Aberrant miRNA profiles associated with chronic benzene poisoning. Exp Mol Pathol 96: 426-430, 2014.
19. Kim JO, Song DW, Kwon EJ, Hong SE, Song HK, Min CK and Kim DH: miR-185 plays an anti-hypertrophic role in the heart via multiple targets in the calcium-signaling pathways. PLoS One 10: e0122509, 2015.

20. Ma X, Shen D, Li H, Zhang Y, Lv X, Huang Q, Gao Y, Li X, Gu L, Xiu S, et al: MicroRNA-185 inhibits cell proliferation and induces cell apoptosis by targeting VEGFA directly in von Hippel-Lindau-inactivated clear cell renal cell carcinoma. Urol Oncol 33: 169.e1-e111, 2015.

21. Bao L,Fu X, Si M, Wang Y,MaR, Ren X and Lv H: MicroRNA-185 targets SOCS3 to inhibit beta-cell dysfunction in diabetes. PLoS One 10: e0116067, 2015.

22. Fu P, Du F, Yao M, Lv K and Liu Y: MicroRNA-185 inhibits proliferation by targeting c-Met in human breast cancer cells. Exp Ther Med 8: 1879-1883, 2014.

23. Wang R, Tian S, Wang HB, Chu DP, Cao JL, Xia HF and Ma X: MiR-185 is involved in human breast carcinogenesis by targeting Vegfa. FEBS Lett 588: 4438-4447, 2014. 